\title{
Flooded wetlands mapping from Sentinel-2 imagery with spectral water index: a case study of Kampinos National Park in central Poland
}

\author{
Tatiana SOLOVEY ${ }^{1, *}$ \\ 1 Polish Geological Institute - National Research Institute, Rakowiecka 4, 00-975 Warszawa, Poland
}

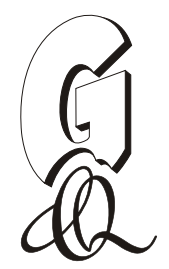

Solovey, T., 2020. Flooded wetlands mapping from Sentinel-2 imagery with spectral water index: a case study of Kampinos National Park in central Poland. Geological Quarterly, 64 (2): 492-505, doi: 10.7306/gq.1509

Associate Editor: Stanisław Wołkowicz

\begin{abstract}
Flood monitoring of wetlands and floodplains is a new issue in remote sensing, as compared to the mapping of open water bodies. The method based on spectral water indices, calculated on the basis of green, red and shortwave infrared bands, is one of the most popular methods for the recognition of a water body in multispectral images. The recently introduced Sentinel-2 satellite can provide multispectral images with high spatial resolution. This new data set is potentially of great importance for flood mapping, due to its free access and the frequent revisit capabilities. In this study, three popular water indices (Modified Normalized Difference Water Index, Normalized Difference Pond Index and Normalized Difference Turbidity Index) were used. The efficiency of the proposed method was tested experimentally using the Sentinel-2 image for the Kampinos National Park in Poland. The experiment compared four extraction algorithms including three based on individual water indicators and one on a combination of them. The results showed that the 10-metre false colour composite produced significantly improved the recognition of flooding in wetland areas by comparison with single spectral water indices. In this way, flooded wetlands were mapped based on the Sentinel-2 data set for the years 2017-2018.
\end{abstract}

Key words: remote sensing, Sentinel-2, flooded wetlands mapping, Modified Normalised Difference Water Index (MNDWI), Normalised Difference Pond Index (NDPI), Normalised Difference Turbidity Index (NDTI).

\section{INTRODUCTION}

Wetlands by definition are intermediate ecosystems between typically aquatic and typically terrestrial ones, formed under the influence of constant or periodic saturation of the ground and characterized by the presence of hydrophilic vegetation and organic deposits. Wetlands play a key role in improving water quality, mitigating floods (Acreman and Holden, 2013; Loveline, 2015) and drought (Ilnicki, 2002), absorbing carbon dioxide and oxygen emissions (Kayranli et al., 2009), providing natural habitats and supporting biodiversity (Tobolski, 2003; Łachacz, 2004; Mitsch, 2009; Mitsch and Gosselink, 2015). Mapping of wetlands has always been necessary, since a register of these areas is obligatory for environmental protection authorities and water management.

Flood inundation is a key hydrological characteristic of floodplain wetlands. High water generates flooding in wetlands, and the range, frequency, duration and depth of flooding determine the distribution, type and vitality of the wetland vegetation. Floods play a key role in supplementing wetland groundwater

*E-mail: tatiana.solovey@pgi.gov.pl

Received: July 12, 2019; accepted: October 4, 2019; first published online: February 6, 2020 stocks. Therefore, it is necessary to monitor the spatial extent of flooding.

Remote sensing has proven to be a useful and frequently used tool for wetlands monitoring, as the data obtained can provide macroscopic, real-time, dynamic information that is not available from in situ technology (Bourgeau-Chavez et al., 2001; Kasischke et al., 2003; Chen et al., 2004; Jones et al., 2009; Brisco et al., 2011; Budzyńska et al., 2011; Du et al., 2011; Feng et al., 2012; Solovey, 2013, 2017; Nandi et al., 2017; Whyte et al. 2018; Wu, 2018). Various methods have been used in wetlands monitoring including single band density slicing (Butera, 1983; Martinez and Le Toan, 2007; Melack and Hess, 2010; Morandeira et al., 2016; Moser et al., 2016), unsupervised and supervised classification (Ramsey and Laine, 1997; Zomer et al., 2009; Mwita et al., 2013; Huang et al., 2014a; Napiórkowska, 2014; White et al., 2015) and spectral water indices (Li and Chen, 2005; Huang et al., 2014b; Li et al., 2016; Nandi et al., 2017). The wetlands mapping method based on spectral water indices is currently very popular because it is easy to apply, efficient and has low computing costs. The most useful spectral water indices for wetland classification are the Normalized Difference Vegetation Index (NDVI; Kayastha et al., 2012), the Land Surface Water Index (LSWI; Dong et al., 2014), the Normalized Difference Water Index (NDWI; McFeeters, 1996; Seiler et al., 2009; Dvorett et al., 2016), Modified Normalized Difference Water Index (MNDWI; Xu, 2006; Davranche et al., 2010) and the Soil and Atmosphere Resistant Vegetation Index (SARVI; Huete et al., 1997). 
MODIS, Landsat and currently, Sentinel satellite images are the most used in monitoring of seasonally flooded wetlands. MODIS data has a low spatial resolution and a high time resolution; on this basis, flooded wetlands cannot be accurately determined as well as providing identification of smaller objects, whereas images with a better spatial resolution, such as Landsat data, always have a low time frequency and a series of irregular images due to clouds. The European Space Agency (ESA) has made great progress in increasing the efficiency of flooded wetlands mapping by introducing a new optical, precise spatial resolution using the Sentinel-2 satellite. Sentinel-2 images have great potential for wetland mapping on a regional scale due to properties such as spatial resolution of $10 \mathrm{~m}$ for four bands and a 10-day return frequency, and free access. Sentinel-2 offers multispectral images and has a total of 13 bands, in which four bands [blue, green, red and Near, Infra, Red (NIR)] have a spatial resolution of $10 \mathrm{~m}$, four vegetation bands of Red Edge and two bands of Short Wave Infra Red (SWIR) have $20 \mathrm{~m}$ resolution, while the Coastal Aerosol, Water Vapor and Cirrus Bands have $60 \mathrm{~m}$ resolution. However, considering the four fine spectral resolution bands, a panchromatic band can be produced and used in Sentinel-2 image fusion for producing ten fine spatial resolution bands (Selva et al., 2015).

This article describes flooded wetlands monitoring using a combination of three spectral water indices to identify floodplains within wetlands including: the Modified Normalized Difference Water Index (MNDWI), the Normalized Difference Pond Index (NDPI) and the Normalized Difference Turbidity In$\operatorname{dex}(N D T I)$. The combination of these indices helps the identification of water reservoirs, water and swamp vegetation and water turbidity, which makes it easy to identify wetlands.

Xu (2006) proposed a MNDWI which uses a short wave infrared (SWIR) beam to replace the NIR band used in NDWI (McFeeters, 1996) as the NDWl indicator is sensitive to built-up areas and often causes overestimation of water reservoirs. Many previous research studies have shown that MNDWI is more suitable for enriching water information and can identify water reservoirs with greater accuracy than NDWI (Xu, 2006; Li et al., 2013; Du et al., 2014; Singh et al., 2015).

NDPI (Lacaux et al., 2007) can effectively capture water and swamp vegetation occurring in wetlands with surface water, in contrast to the classic NDVI (Tucker and Sellers, 1986), which did not work well for vegetation in areas flooded with a shallow layer of water. Lacaux et al. (2007) proposed NDTI, which effectively captures turbid water reservoirs prevalent in wetlands that were often confused with open soil on remote sensing images as the increase in water turbidity and associated radiometric response causes the turbid water reservoirs to behave like open soils (Guyot, 1989). The NDTI indicator uses green and red bands of images from the remote sensing based on the level of water turbidity increasing due to the increase of particles suspended in water, which causes a greater reflection of the red band than the green (Islam and Sado, 2006).

Based on the observed advantages of the MNDWI, NDPI and $N D T I$ indicators as well as the potential of the Sentinel-2 database resources, we decided to test the usefulness of combining these indicators as an RGB composite for mapping flooded wetlands in the Vistula valley. An advantage of this approach is the ease of the method and the availability of Sentinel-2 data, which is particularly important for exploratory mapping with limited resources.

The purpose of this study was to: (1) create a series of temporal composite images of the spectral water indices $M N D W I$, $N D P I$ and NDTI with a spatial resolution of $10 \mathrm{~m}$ based on Sentinel-2 images for the years 2017-2018; (2) flooded wetlands mapping with the use of supervised classification techniques; and (3) assessment of the usefulness of the $10 \mathrm{~m}$ images created in flooded wetlands mapping.

\section{STUDY AREA}

The research area is located in the central part of the Vistula valley in Poland. Part of the Vistula valley discussed in this study is located in the Kampinos National Park (KPN), which is also a Natura 2000 area and spreads over an area of $385 \mathrm{~km}^{2}$ (Fig. 1). The KNP is located in the Central Mazovian Lowland in the Vistula valley, north-west of Warsaw.

The average height of the KPN area, which is generally even, is $\sim 80 \mathrm{~m}$ above sea level (Krogulec, 2004). The landscape here is characterized by latitudinal patterns. From the north spreads the Vistula flood terrace. Farther to the south runs the terrace of the Kampinos Forest consisting of two alternating dune and marshy strips, and the terrace of the Łowicko-Błońska Plain (Krogulec, 2011). The climate is moderate with an average annual temperature over many years (1994-2016) of $8.7^{\circ} \mathrm{C}$ and an average annual precipitation of $568.1 \mathrm{~mm}$ (Olszewski et al., 2018).

The basic ecosystem for which the KNP was established is the valuable natural wetlands, which cover $176.9 \mathrm{~km}^{2}$ (Kopeć et al., 2013). The northern swamp belt, with an area of $\sim 10,000$ ha, is much more developed than the southern one. Most swamps here have been turned into meadows and pastures. The southern swamp belt, with an area of $\sim 7,000 \mathrm{ha}$, is fragmented into several valleys that no longer form a distinct belt. Wet meadows and sedges prevail in this belt (MichalskaHejduk, 2001).

Natural valuable wetland communities of the non-forest areas of the KNP are: variable humidity molinia meadows of Molinion, humid meadows of Molinietalia, extensively used fresh meadows of Arrhenatherion, transition bogs and quaking bogs (mostly with Scheuzerio-Caricetea vegetation), marigold meadows with Calthion, Phragmition rushes and, most widespread, large reed rushes of Magnocaricion (MichalskaHejduk, 2004).

The swamps (forested wetlands) of the KNP are mainly represented by alder and riparian forests, which occupy almost half of the area (8810 ha) of the boggy belt. The red-necked alder Ribeso nigri-Alnetum and the Fraxino-Alnetum ash-alder forest are typical (Michalska-Hejduk et al., 2011). Lowering of groundwater level is clearly considered to be the greatest threat to the nature of the $\mathrm{KPN}$. The main reasons for the degradation of wetlands were the stopping of flooding as a result of the construction of the Vistula and Bzura river embankments as well as drainage channels and ditches (Okruszko et al., 2011). Therefore, it is extremely important to monitor flooded wetlands of the KPN.

\section{DATASET}

The dataset used in this study is the Sentinel-2 Level 1C product (Table 1) in the Universal Transvers Mercator (UTM)/WGS84 projection, which was downloaded from the ESA Sentinel-2 Pre-Operations Hub (https://scihub.copernicus.eu). A subset covering $40 \times 17 \mathrm{~km}$ and cantered at 52024'35"N, 20017'3"E was used for the case study (Fig. 2). The false colour composite of the Sentinel- 2 image at $10 \mathrm{~m}$ resolution of the study area is shown in Figure 2A. The images of the green band at $10 \mathrm{~m}$, the NIR band at $10 \mathrm{~m}$, the SWIR band at $20 \mathrm{~m}$, respectively, are shown in Figure $2 B-D$, and these four 


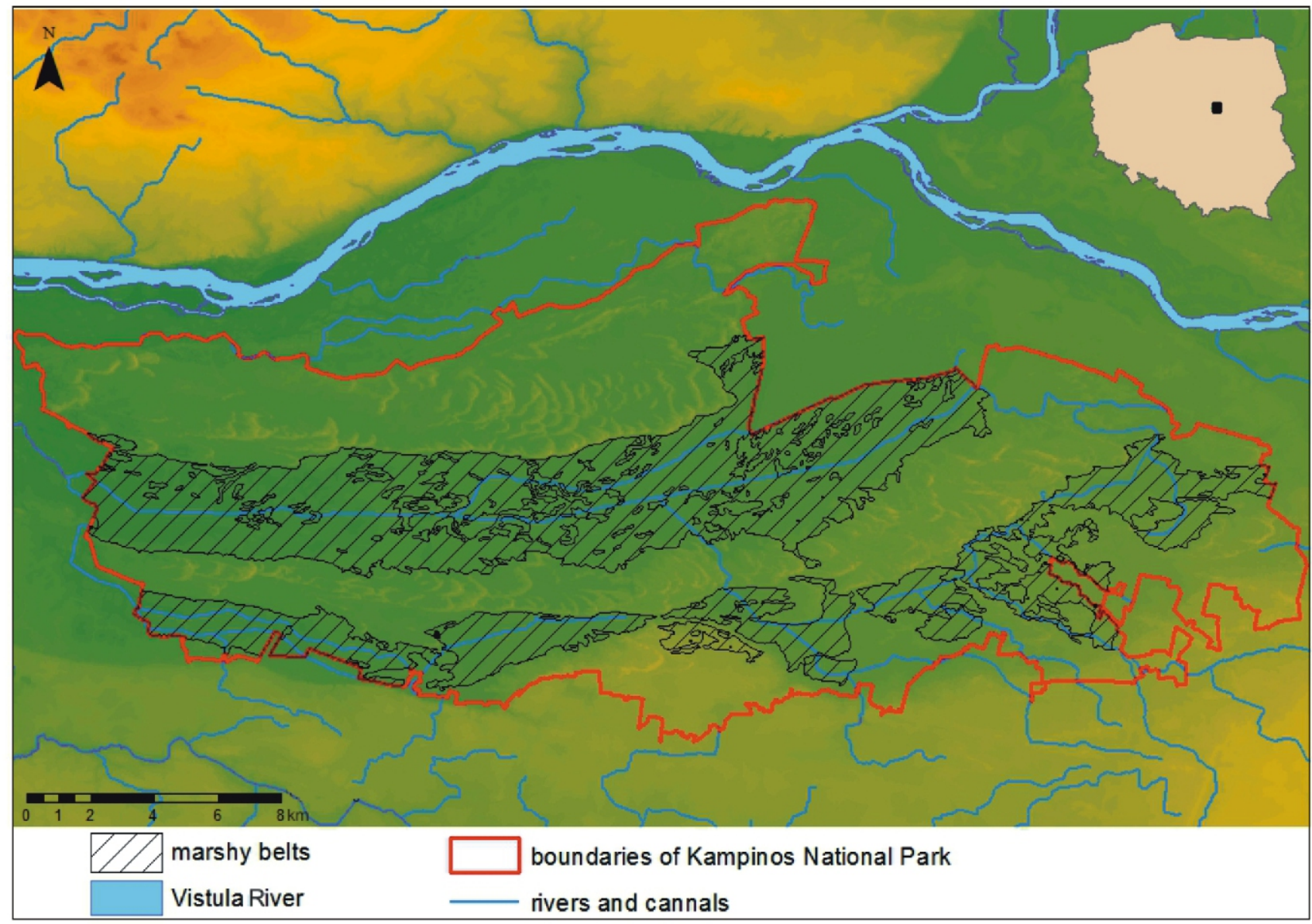

Fig. 1. Location of the study area within a Digital Elevation Model (DTM) of Poland

bands were involved in the calculation of water indices of the MNDWI, NDPI and NDTI. For the analysis, a Sentinel-2 image was used with a zero cloud in 2017-2018. Date of acquisition is shown in Table 2.

\section{METHODOLOGY}

SPECTRAL WATER INDICES

Modified Normalised Difference Water Index (MNDWI). The Modified Normalised Difference Water Index (MNDWI; Xu, 2006) is defined as:

$$
M N D W I=\frac{\rho_{\text {Green }}-\rho_{\text {SWIR }}}{\rho_{\text {Green }}+\rho_{\text {SWIR }}}
$$

where: $\rho_{\text {Green }}$ - the top of the atmosphere (TOA) reflectance value of the green band; $\rho_{S W I R}$ - the TOA reflectance value of the SWIR band 12 .

Compared to the raw digital numbers (DN), the TOA reflectance is more suitable for calculating the MNDWI (Chander et al., 2009; Li et al., 2013; Ko et al., 2015). The freely available Sentinel-2 Level-1C dataset is already a standard product of TOA reflectance (Drusch et al., 2012).

$\mathrm{Tab} \mathrm{e}$

Summary of the remotely sensed datasets used for this study

\begin{tabular}{|c|c|c|c|c|}
\hline Sensor name & Sensor type & Band information & Band numbers & Resolution [m] \\
\hline \multirow{4}{*}{ Sentinel-2 } & Blue $(490 \mathrm{~nm})$ & Band 2 & 10 \\
\cline { 3 - 5 } & \multirow{4}{*}{ optical } & Green $(560 \mathrm{~nm})$ & Band 3 & 10 \\
\cline { 3 - 5 } & & $\operatorname{Red}(665 \mathrm{~nm})$ & Band 4 & 10 \\
\cline { 3 - 5 } & & $\operatorname{NIR}(842 \mathrm{~nm})$ & Band 8 & 10 \\
\cline { 3 - 5 } & & $\operatorname{SWIR}(1610 \mathrm{~nm})$ & Band 11 & 20 \\
\cline { 3 - 5 } & & $\operatorname{SWIR~}(2190 \mathrm{~nm})$ & Band 12 & 20 \\
\hline
\end{tabular}



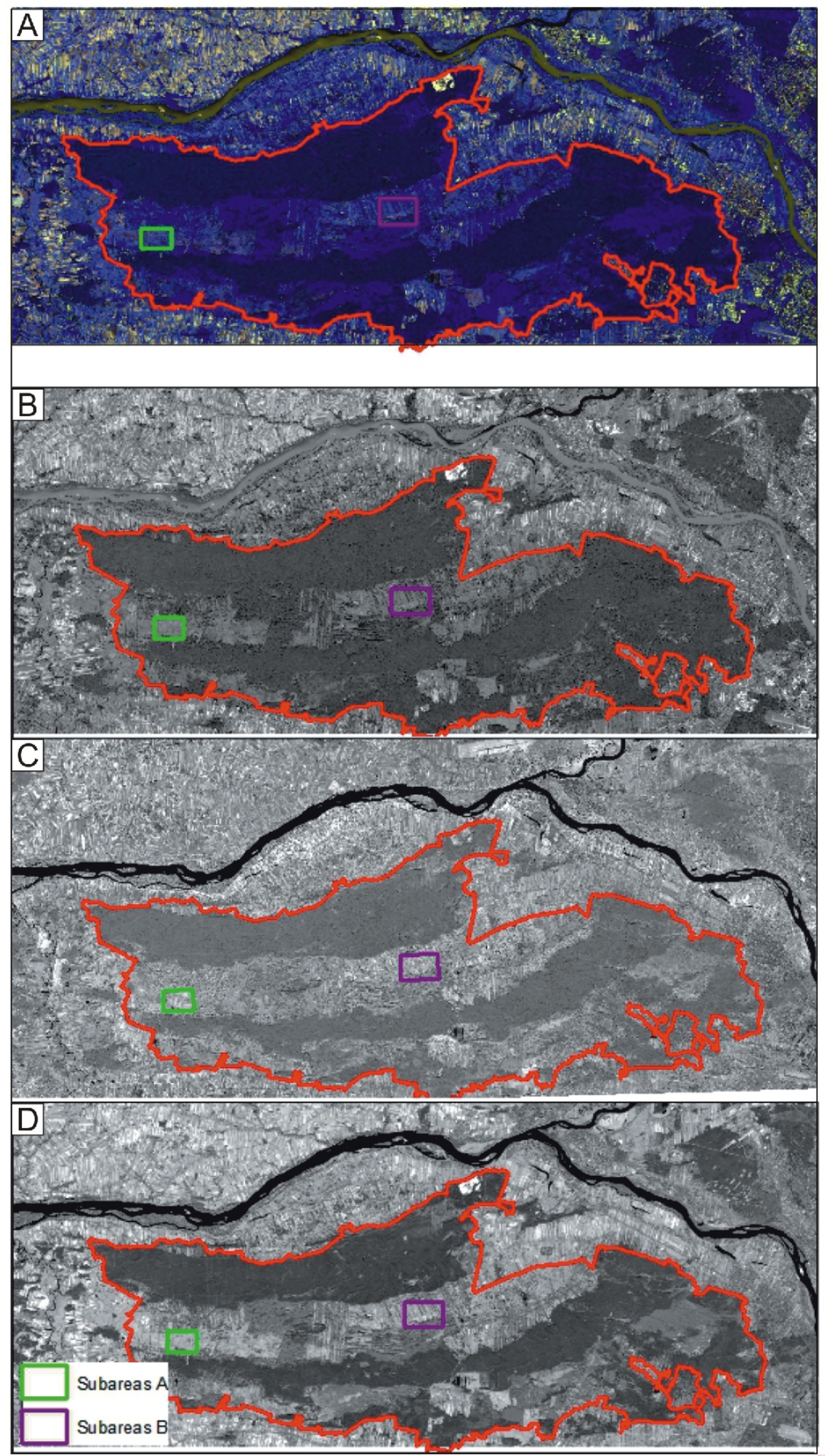

Fig. 2. Image acquired on 2 October 2017

A - 10 metre false colour map (R: Band 4; G: Band 3; B: Band 8) study area; B - 10 m green Band 3; C - $10 \mathrm{~m}$ red Band 8; D- $20 \mathrm{~m}$ SWIR Band 11; the two square frames shown indicate the locations of subareas $A$ and $B$ 
Maximum (Max), minimum (Min), mean and standard deviation (SD) values of water bodies and flooded wetlands within the MNDWI, NDTI and NDPI

\begin{tabular}{|c|c|c|c|c|c|c|c|c|c|}
\hline \multirow[b]{2}{*}{$\begin{array}{l}\text { Acquisition } \\
\text { date }\end{array}$} & \multirow[b]{2}{*}{ Water indices } & \multicolumn{2}{|c|}{ Min. } & \multicolumn{2}{|c|}{ Max. } & \multicolumn{2}{|c|}{ Mean } & \multicolumn{2}{|c|}{ SD } \\
\hline & & $\begin{array}{l}\text { water } \\
\text { body }\end{array}$ & $\begin{array}{c}\text { flood. } \\
\text { wetland }\end{array}$ & $\begin{array}{l}\text { water } \\
\text { body }\end{array}$ & $\begin{array}{c}\text { flood. } \\
\text { wetland }\end{array}$ & $\begin{array}{l}\text { water } \\
\text { body }\end{array}$ & $\begin{array}{l}\text { floodD. } \\
\text { wetland }\end{array}$ & $\begin{array}{l}\text { water } \\
\text { body }\end{array}$ & $\begin{array}{l}\text { flood. } \\
\text { wetland }\end{array}$ \\
\hline \multirow{3}{*}{$\begin{array}{l}29 / 03 / 2017 \\
\text { vegetation } \\
\text { period }\end{array}$} & MNDWI & 0.44 & -0.38 & 0.77 & 0.42 & 0.65 & 0.03 & 0.06 & 0.17 \\
\hline & NDPI & 0.39 & -0.54 & 0.74 & 0.30 & 0.61 & -0.19 & 0.07 & 0.18 \\
\hline & NDTI & -0.04 & -0.16 & 0.04 & 0.14 & 0.00 & 0.01 & 0.02 & 0.06 \\
\hline \multirow{3}{*}{$\begin{array}{l}2 / 10 / 2017 \\
\text { vegetation } \\
\text { period }\end{array}$} & MNDWI & -0.37 & -0.68 & 0.81 & -0.47 & 0.25 & -0.57 & 0.24 & 0.04 \\
\hline & NDPI & -0.48 & -0.80 & 0.77 & -0.66 & 0.10 & -0.73 & 0.25 & 0.03 \\
\hline & NDTI & -0.36 & 0.04 & 0.14 & 0.30 & -0.18 & 0.18 & 0.13 & 0.06 \\
\hline \multirow{3}{*}{ 26/12/2017 } & MNDWI & 0.12 & -0.37 & 0.40 & 0.03 & 0.24 & -0.14 & 0.05 & 0.08 \\
\hline & NDPI & 0.13 & -0.35 & 0.39 & 0.03 & 0.25 & -0.17 & 0.06 & 0.08 \\
\hline & NDTI & -0.11 & -0.14 & 0.13 & 0.23 & 0.01 & -0.02 & 0.05 & 0.07 \\
\hline \multirow{3}{*}{$8 / 01 / 2018$} & MNDWI & 0.40 & 0.21 & 0.92 & 0.59 & 0.64 & 0.39 & 0.14 & 0.08 \\
\hline & NDPI & 0.27 & 0.08 & 0.98 & 0.47 & 0.58 & 0.31 & 0.14 & 0.08 \\
\hline & NDTI & -0.49 & -0.04 & 0.03 & 0.18 & -0.18 & 0.08 & 0.11 & 0.05 \\
\hline \multirow{3}{*}{$\begin{array}{l}19 / 03 / 2018 \\
\text { vegetation } \\
\text { period }\end{array}$} & MNDWI & 0.42 & -0.26 & 0.64 & 0.48 & 0.53 & 0.17 & 0.05 & 0.17 \\
\hline & NDPI & 0.36 & -0.39 & 0.59 & 0.37 & 0.48 & 0.03 & 0.05 & 0.19 \\
\hline & NDTI & -0.04 & -0.01 & 0.03 & 0.11 & 0.00 & 0.03 & 0.01 & 0.03 \\
\hline
\end{tabular}

Compared to $\operatorname{NDWI}(\mathrm{Gao}, 1996)$, water bodies have greater positive values in the MNDWI because water bodies absorb more SWIR light than NIR light; soil, vegetation and built-up areas have smaller negative values because they reflect more SWIR light than green light (Sun et al., 2012).

The Normalised Difference Water Index (MNDWI; Gao, 1996) is defined as:

$$
N D W I=\frac{\rho_{\text {Green }}-\rho_{N I R}}{\rho_{\text {Green }}+\rho_{N I R}}
$$

where: $\rho_{\text {Green }}$ - the TOA reflectance value of the green band; $\rho_{N I R}-$ the TOA reflectance value of the NIR band.

For Sentinel-2, the green band has a spatial resolution of $10 \mathrm{~m}$, while the SWIR band (Band 12) has a spatial resolution of $20 \mathrm{~m}$. Thus, the MNDWI needs to be calculated at a spatial resolution of either 10 or $20 \mathrm{~m}$. In this study, the spatial resolution of the SWIR band was increased from 20 to $10 \mathrm{~m}$ by using pan-sharpening algorithms. For this purpose, the High Pass Filter (HPF) was selected (Chavez et al., 1991) because the HPF produces a sharpened $10 \mathrm{~m} \mathrm{SWIR}$ band with a higher quality with no reference (QNR) value.

If the spatial resolution of Band 12 is increased from 20 to $10 \mathrm{~m}$, the MNDWI with a spatial resolution of $10 \mathrm{~m}, M N D W I_{10 \mathrm{~m}}$, can then be calculated as:

$$
M N D W I_{10 m}=\frac{\rho_{3}-\rho_{12}^{10 m}}{\rho_{3}+\rho_{12}^{10 m}}
$$

where: $\rho_{3}$ - the TOA reflectance value of the green band and refers to the TOA reflectance value of Band 12 at $10 \mathrm{~m}$, which is produced by downscaling the original $20 \mathrm{~m}$ Band 12 . This is achieved by using pan-sharpening algorithms.
Normalised Difference Pond Index (NDPI). The classic $N D V I$ did not work well in the case of vegetation in wetlands covered with a shallow layer of water, which is why the NDPI was developed.

The Normalised Difference Pond Index (NDPI; Lacaux et al., 2007) is defined as:

$$
N D P I=\frac{\rho_{\text {Green }}-\rho_{\text {SWIR }}}{\rho_{\text {Green }}+\rho_{\text {SWIR }}}
$$

where: $\rho_{S W I R}$ - the TOA reflectance value of the SWIR Band 11; $\rho_{\text {Green }}$ - the TOA reflectance value of the green band.

As in the case of the MNDWI, for the NDPI calculation, the spatial resolution of the SWIR band Sentinel-2 band should be increased from 20 to $10 \mathrm{~m}$ by using pan-sharpening algorithms based on the High Pass Filter (HPF).

The NDPI with a spatial resolution of $10 \mathrm{~m}, N D P I_{10 \mathrm{~m}}$, can then be calculated as:

$$
N D P I_{10 m}=\frac{\rho_{3}-\rho_{11}^{10 m}}{\rho_{3}+\rho_{11}^{10 m}}
$$

where: $\rho_{11}^{10 m}$ refers to the TOA reflectance value of Band 11 at $10 \mathrm{~m}$, which is produced by downscaling the original $20 \mathrm{~m}$ Band 11 and $\rho_{3}$ is the TOA reflectance value of the green band.

NDTI. The Normalised Difference Turbidity Index (NDTI) (Lacaux et al., 2007) is defined as:

$$
N D T I=\frac{\rho_{\text {Red }}-\rho_{\text {Green }}}{\rho_{\text {Red }}+\rho_{\text {Green }}}
$$

where: $\rho_{\text {Red }}$ - the TOA reflectance value of the red band; $\rho_{\text {Green }}-$ the TOA reflectance value of the green band. 

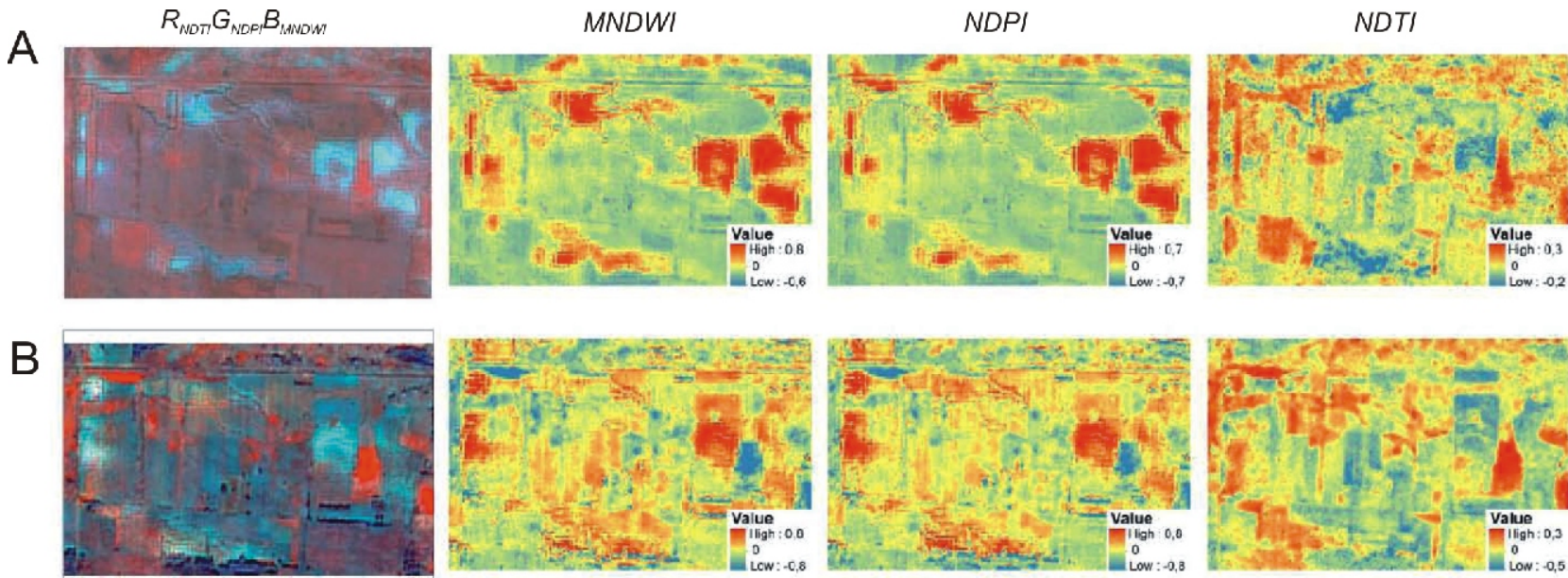

C
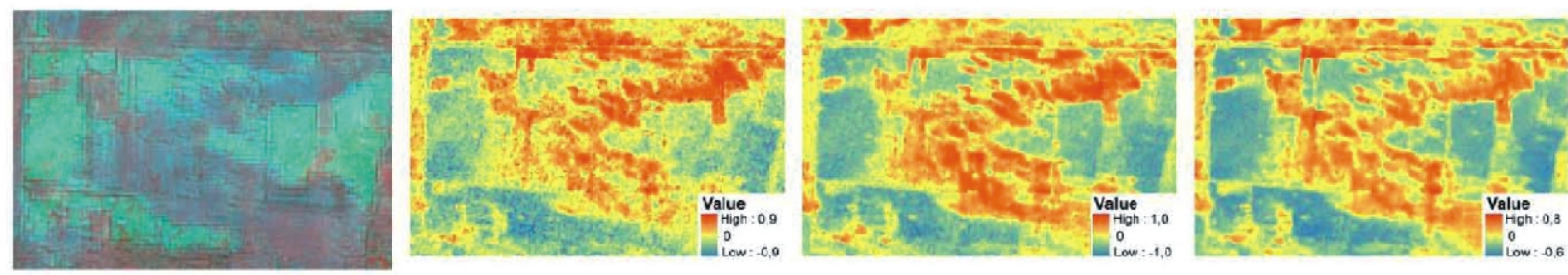

D
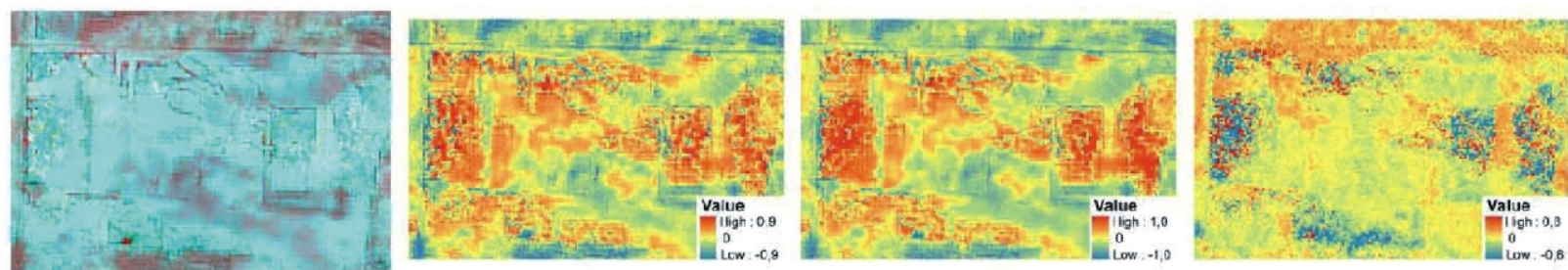

$\mathrm{E}$
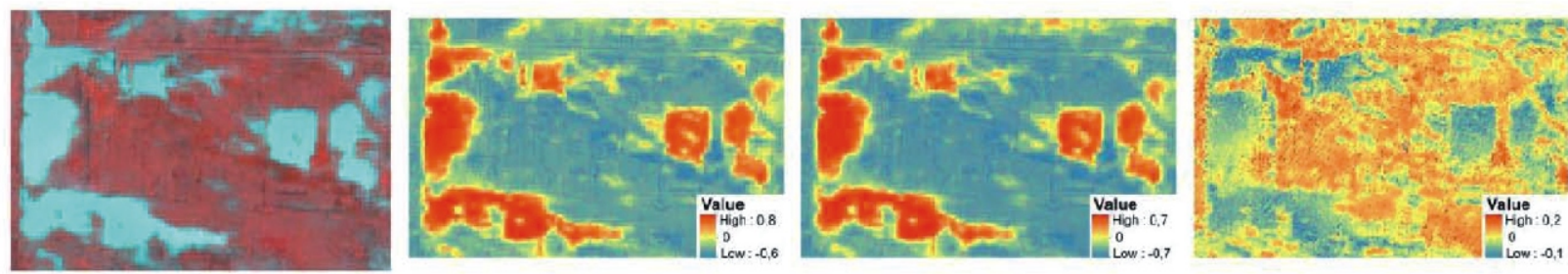

Fig. 3. Subarea $A$ of the $10 \mathrm{~m}$ false colour composite $R_{N D T I} G_{N D P I} B_{M N D W I}, M N D W I, N D P I$ i $N D T I$ image for acquisition dates: (A) 29.03.2017; (B) 2.10.2017; (C) 26.12.2017; (D) 8.01.2018; and (E) 19.03.2018

\section{FLOODED WETLANDS MAPPING AND ASSESSING} THE ACCURACY OF RESULTS

After the creation of the MNDWI, NDPI and NDTI, floodplain wetlands can be mapped based on a false colour composite of Red (NDTI), Blue (MNDWI) and Green (NDPI). The tests carried out to select the colour composition that allows the best recognition of the objects discussed show that in the $R_{N D T /} G_{N D P \mid} B_{M N D W 1}$ composition the floodplain wetlands are presented in a more expressive way.

The next stage is related to the performance of a pixel classification supervised by the maximum likelihood method (Lewiński, 2007) in the Erdas Imagine environment. When deciding on the choice of classes, it was noted that the classes were represented by homogeneous objects, regarding the identification of which there is no doubt. Based on the analysis of the spectral characteristics of the initially selected classes, it was decided to separate 2 classes of objects, which are:

1. Water reservoirs (water bodies);
2. Flooded wetlands with a translucent plant cover (in the research area mainly from Phragmition, SparganioGlycerion and Magnocaricion compounds).

The definition of flooded wetlands in forest areas was abandoned due to the inability to clearly define this class based on the applied $R_{N D T /} G_{N D P \mid} B_{M N D W /}$ composition. The selection of the right scatter plot is made on the basis of field observations and use of a numerical terrain model, assuming that the outflow depressions have the highest probability of flooding. In order to verify the correctness of the training fields selected for individual classes, the spectral distance method according to Jeffreys-Matusit (Jensen, 1996) was used. The measurement of the spectral distance JMab was calculated using the formula (Jensen, 1996):

$$
J M_{a b}=\sqrt{2\left(1-e^{B h a t_{a b}}\right)}
$$

where: $J M_{a b}-\mathrm{J}-\mathrm{M}$ distance between classes a and b, Bhat ${ }_{a b}-$ Bhattacharyya distance between classes $a$ and $b$. 

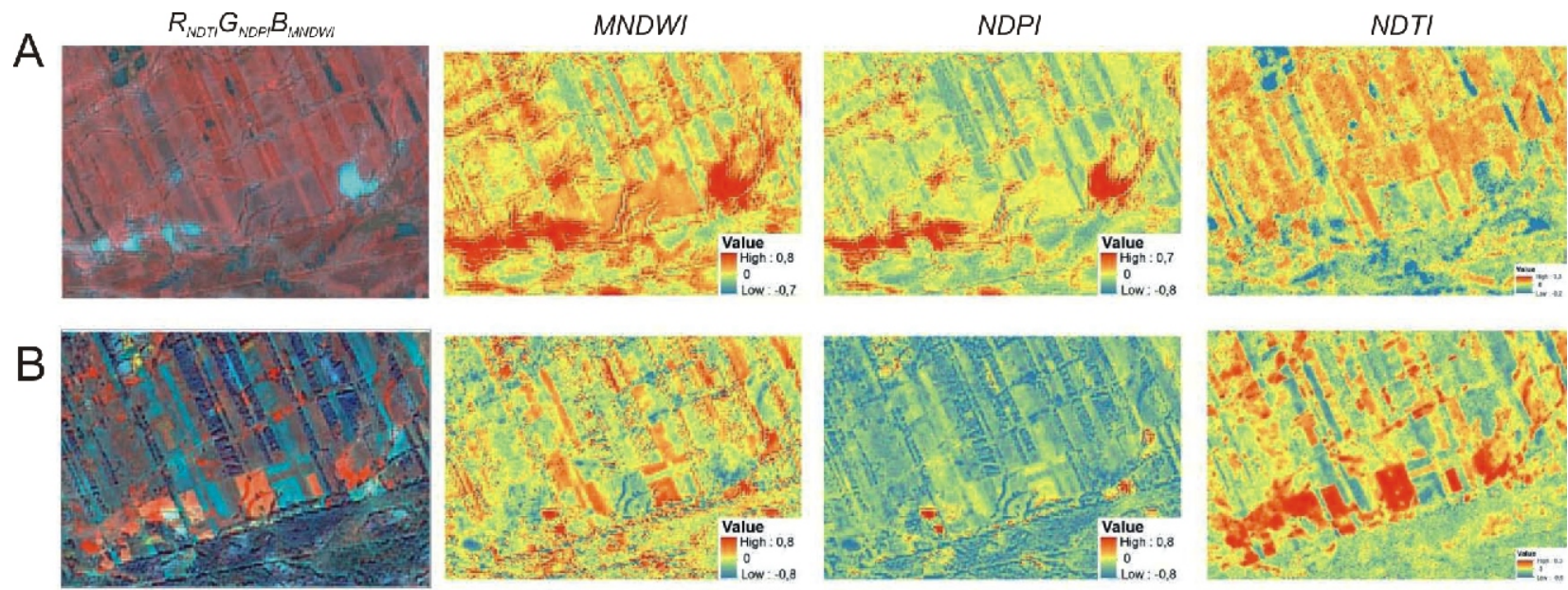

C
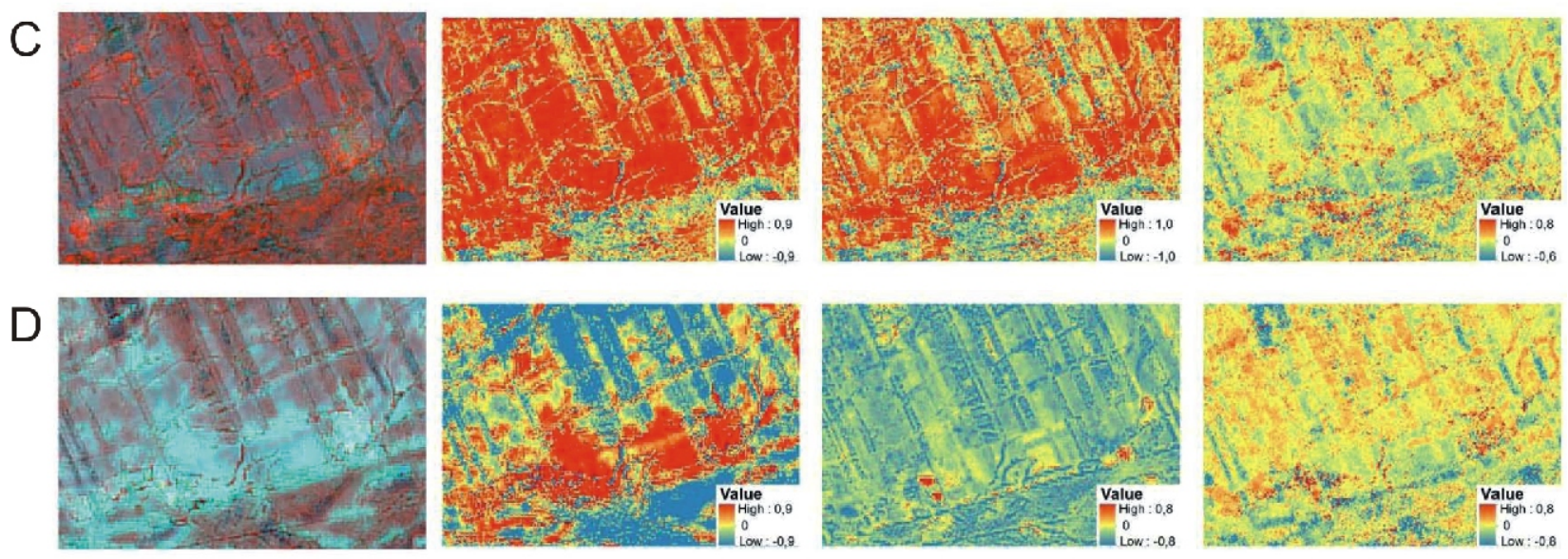

$\mathrm{E}$
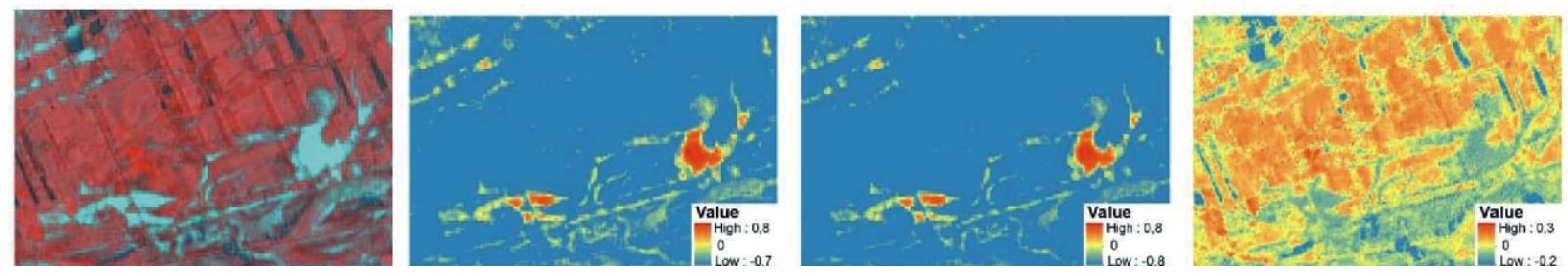

Fig. 4. Subarea $B$ of the $10 \mathrm{~m}$ false colour composite $R_{N D T I} G_{N D P I} B_{M N D W I}, M N D W I, N D P I$ i $N D T I$ image for acquisition dates: (A) 29.03.2017; (B) 2.10.2017; (C) 26.12.2017; (D) 8.01.2018; and (E) 19.03.2018

A threshold for the maximum spectral distance $J M_{a b}$ equal to 2 was used, indicating complete class separation.

In this study, the overall accuracy (OA) and Kappa coefficient were used to assess the classification accuracy on the basis of the error matrix (Foody, 2002). Monserud and Leemans (1992) suggested that Kappa coefficient values $<0.4$ represent poor or very poor agreement, values from 0.4 to 0.55 represent fair agreement, values from 0.55 to 0.7 represent good agreement, values from 0.7 to 0.85 represent very good agreement, and values $>0.85$ represent an excellent agreement between images.

The analysis was divided into three main stages:

1. Automatic detection of flood extent using image threshold segmentation based on threshold values for the MNDWI, NDPI and NDTI;

2. Semi-automatic detection of the extent of flooding using the classification supervised by the colour composite of Red $(N D T I)$ - Blue (MNDWI) - Green (NDPI);

3. Validation of flooded and water body maps based on the Kappa coefficient.

\section{RESULTS AND DISCUSSION}

The analysis was carried out in the pre- and post-vegetative period in 2017-2018, when Sentinel-2 images with no clouds were available (Table 2). For each acquisition date for subareas $A$ and $B$ four water index images were developed, $R_{N D T I} G_{N D P I} B_{M N D W I}, M N D W I, N D P I$ and NDTI, as shown in Figures 3 and 4 . The results of the detection of flooded wetlands and water body images in Figure 2 were compared.

For water bodies, most MNDWI values are $>0.5$, while NDPI values for them are $>0.3$. The MNDWI indicator provides the best distinguishability of water body compared to NDPI and NDTI. Poor suitability for identification of a water body is indicated by the NDTI index, because the water mapping values (from -0.03 to 0.03 ) are mostly similar to arable land with a vegetation cover.

For flooded wetlands with a translucent plant cover, the MNDWI values are very different, as shown in Figures 3 and 4. In comparison with a water body, flooded wetlands with a translucent plant cover have much lower MNDWI values. Outside 
the vegetation period, the differences between the MNDWI values of water bodies and flooded wetlands are reduced. The weakness of the MNDWI indicator is the similarity between flooded wetlands and arable land without vegetation. By using the NDPI indicator, flooded wetlands can be slightly differentiated compared to the MNDWI indicator. The NDTI indicates the worst results, but its advantage is the detectability of rush vegetation, which indirectly identifies seasonally flooded wetlands. In comparison to the water body, flooded wetlands are less well captured on images with single water indices. The combination of these indices strengthens the range of areas flooded with water and covered with water and swamp vegetation, which allows the most precise identification of floodplain wetlands.

Table 2 contains a list of statistical parameters of training fields for water bodies and flooded wetlands with reference to water indices - MNDWI, NDTI, NDPI.

For flooded wetlands, the minimum, maximum and average values of $M N D W I$ are smaller than the MNDWI values for a water body. These differences vary depending on the stage of development of swamp vegetation. In autumn, these differences reach their largest sizes, against slightly smaller differences in the early spring period, and they are minimal in winter. The standard deviation in winter for water bodies and flooded wetlands shows similar low values. In contrast, in early spring the value of standard deviation increases significantly for flooded wetlands. To sum up, based on MNDWI, worse classification results due to poor distinguishability of water bodies and flooded wetlands can be expected in winter and the best results available in early spring. In autumn, due to the green colour of water bodies, the classes analysed are often confused.

A similar trend to that of the MNDWI is shown by the NDPI. The average NDPI value compared to the average MNDWI value is mostly $\sim 0.05$ for water bodies and $\sim 0.15$ for flooded wetlands. Using NDPI, you can best separate the water reservoir from flooded wetlands based on a threshold of zero. Flooded wetlands with a translucent vegetation cover compared to water bodies always have an NDPI value below or around zero. The only exception is when the wetlands were flooded with water above the vegetation cover such as happened on January 8, 2018.

Using the NDTI, worse results of extraction of water body and flooded wetlands are obtained in comparison with the MNDWI and NDPI. However, based on the NDTI, better discrimination can be achieved between water bodies and flooded wetlands. Most of the NDTI values of water body are $<0$, against a background of very different values for flooded wetlands.

Figure 5 shows the diagrams of scattering of brightness values of pixels of a training field for water index pairs: MNDWI and $N D T I, M N D W I$ and $N D P I$ as well as NDTI and NDPI. Training fields have been defined for 5 classes, which are: water body, flooded wetlands, arable land with vegetation cover, arable land without plant cover, and forests. The least separated class on all graphs is arable land without a plant cover, which sporadically shows similar values to water indices from flooded wetlands.

Based on the pair of MNDWI and NDTI, the worst isolation results were obtained between the classes analysed. In this case, the spectral similarity of arable land without vegetation cover and flooded wetlands is clearly visible.

On the basis of the NDTI and NDPI pair, a supposedly low level of separation between classes of arable land without vegetation cover and flooded wetlands is obtained, but the quality of separation of arable land without vegetation cover and water bodies is improved, because shallow and turbid water body in the area of research have similar features to open soil.
On the basis of a pair of MNDWI and NDPI, the best separation results are obtained between the majority of classes, except forests and arable land with a vegetation cover.

When deciding on the selection of an optimal set of spectral water indices for flooded wetlands classification, attention was drawn to the distance between classes in the graphs depicted in Figure 5. It was found that in the early spring period the best results of the flooded wetlands classification are ensured by the combination of the MNDWI and NDPI indices (Fig. 5A, E). In winter (no snow cover) and late autumn, the best flooded wetlands results can be achieved by combining the MNDWI, $N D P I$ and NDTI indices (Fig. 5B-D). Addition of the NDTI improves the separation of flooded wetlands from arable land without plant cover.

The final flooded wetlands maps were made on the basis of the supervised classification using the combination of water indices as a false colour composite $R_{N D T /} G_{N D P I} B_{M N D W l}$ and training fields for two classes - water bodies and flooded wetlands. Five maps were obtained, parts of which for subarea $A$ and $B$ are shown in Figures 6 and 7. On the maps flooded wetlands are shown in brown, water bodies are blue.

In the classification performed, 0.25 ha was assumed as the reference unit. The size of the adopted reference unit results from the interpretation assumptions, according to which, in the course of visual interpretation, objects with dimensions of $5 \times 5 \mathrm{~mm}$ can be defined and recognized on the scale of the map. This means that on a scale of 1:10 000 (on the scale of the satellite image interpretation), one can in practice recognize an area of 0.25 ha.

Figures 6 and 7 show a high level of recognition of non-forest flooded wetlands out of the growing season (Figs. 6B-D and $7 \mathrm{~B}-\mathrm{D})$. In the vegetation period, the recognition of non-forest flooded wetlands is significantly worse (Figs. 6A, E and 7A, E). Then only low vegetated wetlands can be mapped, for example those with sparsely vegetated areas with short grasses and small wetland plant species. It is not possible to discern water on the surface in highly vegetated areas, consisting of larger species of vegetation (e.g., Phragmition and Magnocaricion). The applied false colour composite $R_{N D T /} G_{N D P \mid} B_{M N D W l}$ ensures satisfactory differentiation of water bodies from flooded areas based on the object-pixel heterogeneity feature. Water bodies are characterized by a homogeneous object-pixel texture in contrast to clearly heterogeneous images of flooded areas.

The key problem in the classification was the similar pixel vividness for flooded wetlands and arable land without a plant cover. With the help of the NDVI index, arable land without plant cover was effectively eliminated, leaving only vegetation in wetlands and in water. In general, flooded agricultural areas, especially grasslands, have been found to strongly overlap with flooded wetlands. Due to the author's considerable experience in recognizing wetlands in the research area, the flooded agricultural areas were expertly eliminated. This situation allows us to conclude that the applied false colour composite $R_{N D T /} G_{N D P I} B_{M N D W I}$ allows effective separation of all flooded areas. However, the separation of flooded wetlands requires the introduction of additional interpretational indicators. In this case, the NDVI indicator was used. The method based on the combination of Sentinel-1 and Sentinel-2 radar data also show good results of flooded wetlands separation from flooded agricultural areas (Whyte, 2018).

Overall accuracy (OA) and Kappa indicators were used to quantify the accuracy of flooded wetlands maps of regions $A$ and $\mathrm{B}$. Table 3 shows that the maps originating from the data as of $29 / 03 / 2017,26 / 12 / 2017$ and $19 / 03 / 2018$ have a relatively similar high accuracy because a poorly developed vegetation 

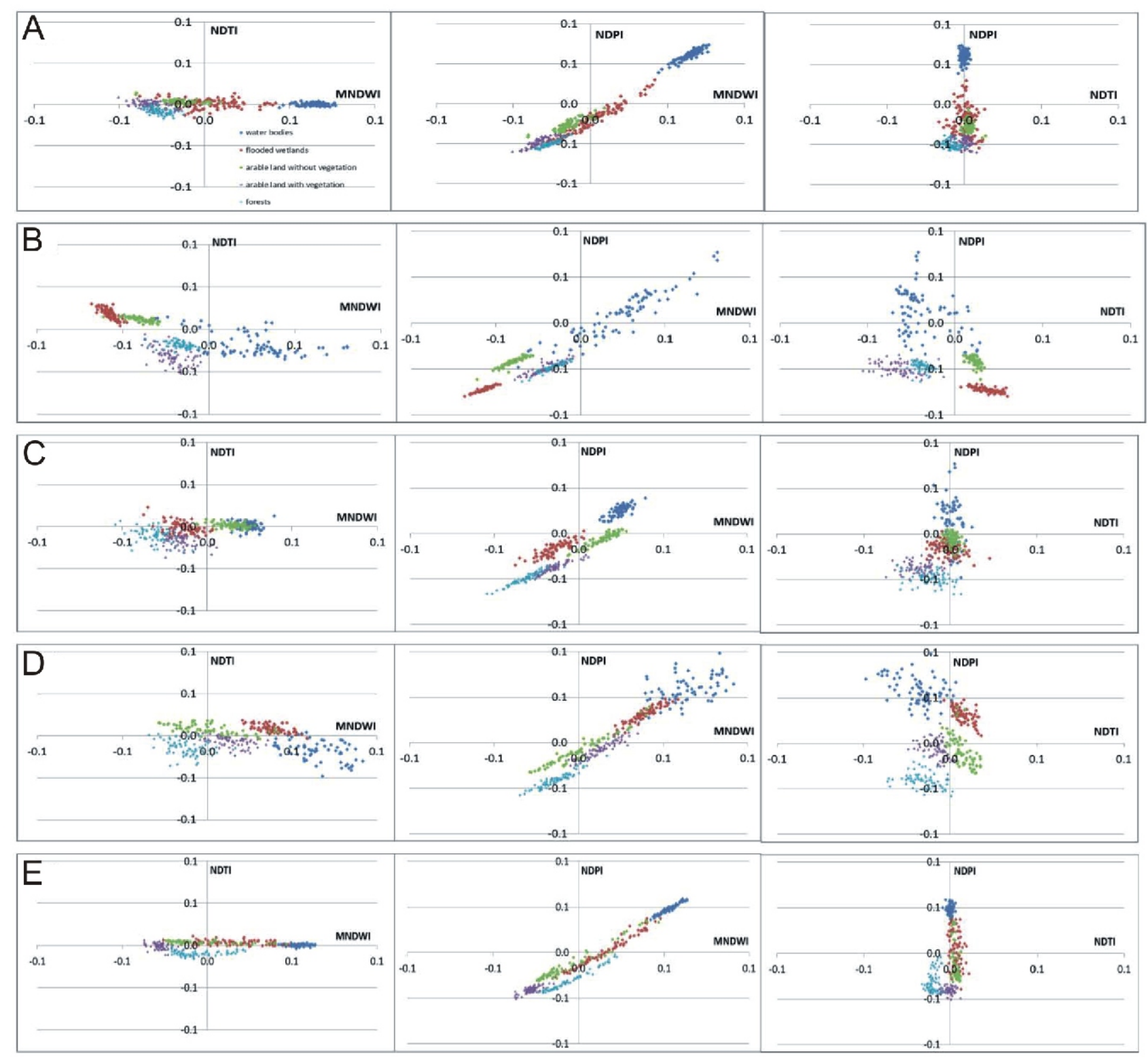

Fig. 5. Graphs of scattering of brightness values of pixels of training fields for water index pairs MNDWI and NDTI, MNDWI and NDPI as well as for NDTI and NDPI for acquisition dates: (A) 29.03.2017; (B) 2.10.2017; (C) 26.12.2017; (D) 8.01.2018; and (E) 19.03.2018

cover or its absence promotes the visibility of the water surface. The maps as of 08/01/2018 show slightly worse accuracy due to the presence of slight snowfall. The largest errors are obtained in the period of active biomass development, exemplified on October 2, 2017.

Thanks to the approach based on multilateral trials and errors, it has been found that a heterogeneous wetland environment can be satisfactorily divided into segments to generate flooded areas. It has been demonstrated that individual spectral water indicators are not sufficient to identify flooding within the varied wetlands landscapes, that are difficult to segment. The $M N D W I$ indicator, which was effective in identifying water bodies, did not provide recognition of flooded vegetation. Therefore, a synergistic approach may be more effective, as was found in this study using a combination of spectral water indica- tors visualized by the false colour composite $R_{N D T /} G_{N D P I} B_{M N D W 1}$. The results of flood mapping tested in two regions within the Kampinos National Park show fairly good results, where the overall map accuracy is $>90 \%$, and the Kappa coefficient is $>0.80$. However, the approach applied does not work in forest areas and shows worse efficacy at times of luxuriant vegetation development. The Sentinel-2 data experiment also showed that the approach taken is useful for mapping flooding in general, not only in wetland areas. Very good results of identifying flooding have been obtained for agricultural land.

The analysis of seasonal changes in flooding has shown a large variability in the ranges of flooded areas. In moist periods, the area of flooded areas within sub-regions $A$ and $B$ is greater by 7.2 times compared to the dry period. Quite a large increase in the extent of flooding in wet periods in the research 

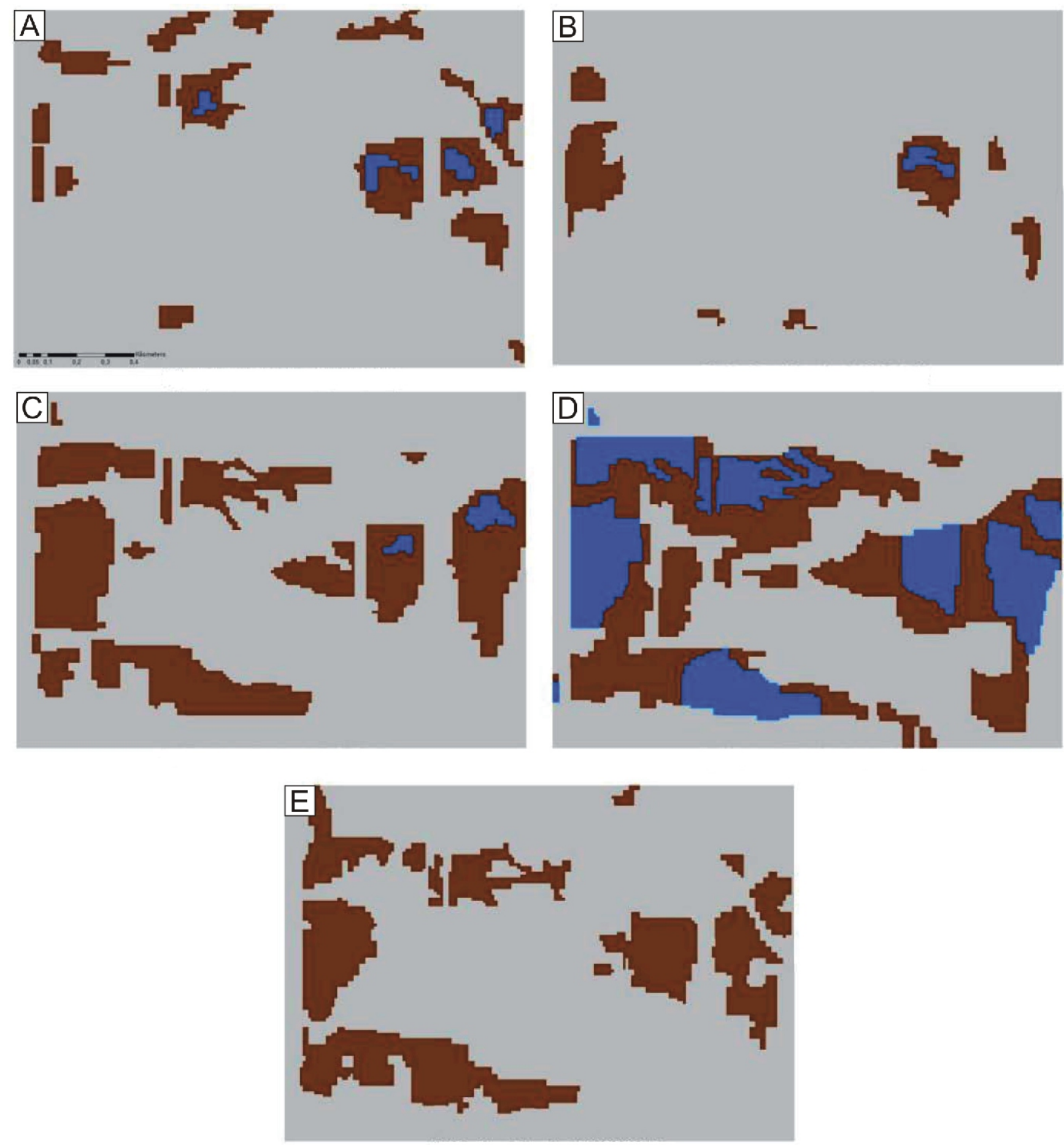

Fig. 6. Subarea $A$ of the $10 \mathrm{~m}$ false colour composite $R_{N D T I} G_{N D P I} B_{M N D W I}$ and the resulting maps of flooded wetlands for acquisition dates: (A) map of flooded wetlands (29.03.2017); (B) map of flooded wetlands (2.10.2017); (C) map of flooded wetlands (26.12.2017); (D) map of flooded wetlands (8.01.2018); (E) map of flooded wetlands (19.03.2018) 

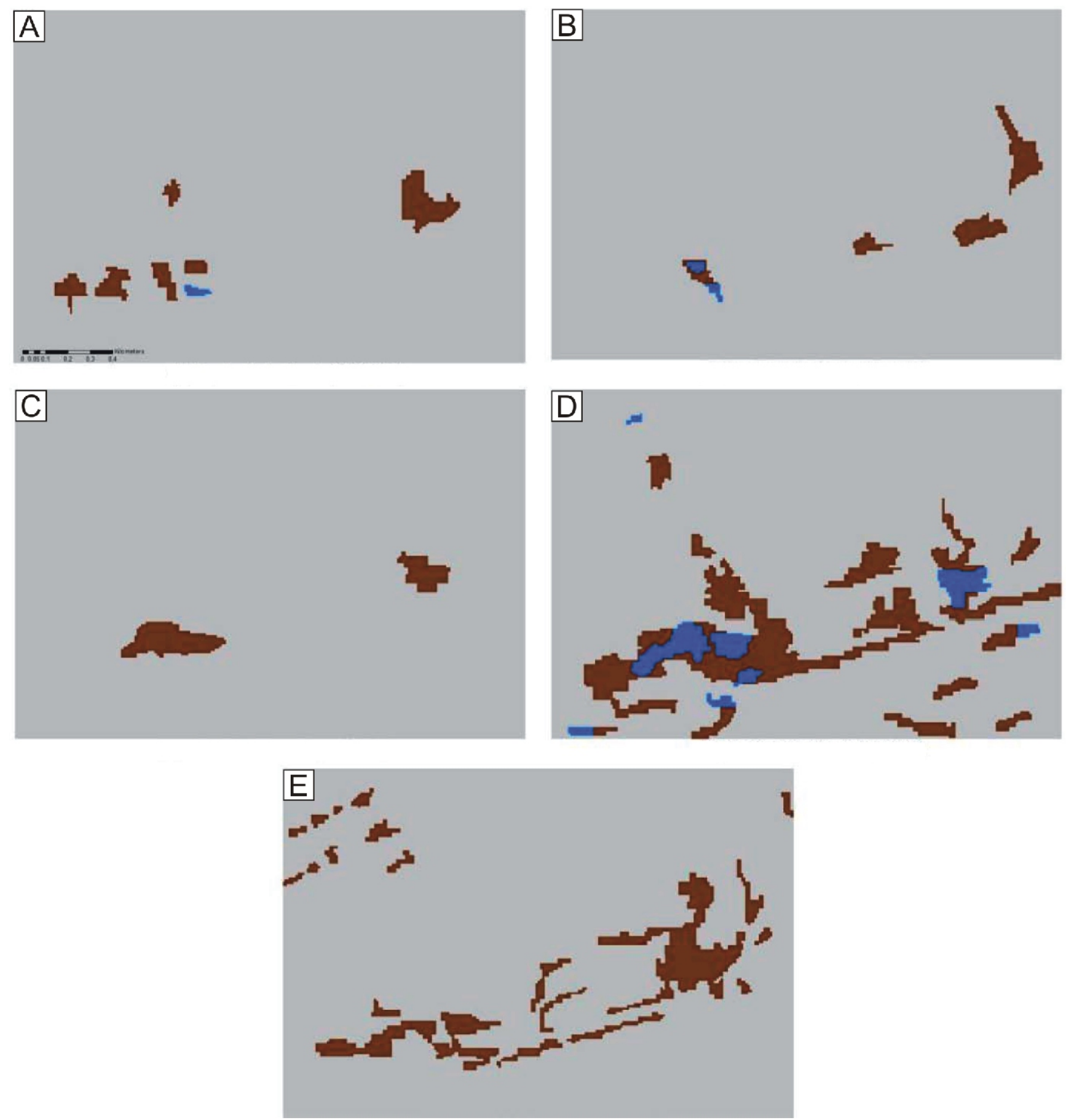

Fig. 7. Subarea $B$ of the $10 \mathrm{~m}$ false colour composite $R_{N D T I} G_{N D P I} B_{M N D W I}$ and the resulting maps of flooded wetlands for acquisition dates: (A) map of flooded wetlands (29.03.2017); (B) map of flooded wetlands (2.10.2017); (C) map of flooded wetlands (26.12.2017); (D) map of flooded wetlands (8.01.2018); (E) map of flooded wetlands (19.03.2018) 
Ta ble 3

Kappa and overall accuracy (OA) of resultant flooded wetlands maps in subareas $A$ and $B$

\begin{tabular}{|l|c|c|c|c|c|c|}
\hline \multirow{2}{*}{ Accuracy indicators } & \multicolumn{5}{|c|}{ Acquisition date } \\
\cline { 3 - 7 } \multicolumn{2}{|c|}{} & $29 / 03 / 2017$ & $2 / 10 / 2017$ & $26 / 12 / 2017$ & $8 / 01 / 2018$ & $19 / 03 / 2018$ \\
\hline \multirow{2}{*}{ Kappa } & A & 0.8700 & 0.8334 & 0.8905 & 0.8579 & 0.8971 \\
& B & 0.8954 & 0.8289 & 0.8828 & 0.8756 & 0.9070 \\
\hline \multirow{2}{*}{ OA } & A & $97.61 \%$ & $97.13 \%$ & $94.67 \%$ & $93.12 \%$ & $94.99 \%$ \\
& B & $94.91 \%$ & $94.28 \%$ & $96.02 \%$ & $97.78 \%$ & $96.79 \%$ \\
\hline
\end{tabular}

area is related to the impeded outflow of rainwater due to the flat topography and poor surface permeability. Peatbogs show the most stable trend of surface variability. On the other hand the highest variability was observed in flood waters along ditches and drainage channels, in which water accumulates only for short periods after rains, but during the dry season they become dry. Moreover, the observations have shown that a poorly located drainage network, which often intersects the natural drainage routes of rainwater and thereby blocks outflow, intensifies flooding in the research area. Our results show the effectiveness of the method of re-naturalization of the Kampinos National Park Wetlands by stopping the land use proposed by Kopeć et al. (2013).

\section{CONCLUSIONS}

The newly introduced Sentinel-2 system provides high resolution multispectral images and a satisfactory time resolution, thereby producing an important data set for mapping of floods. This paper proposes a new method of mapping of flooding from Sentinel-2 images by creating a $10 \mathrm{~m}$ false colour composite $R_{N D T /} G_{N D P \mid} B_{M N D W I}$ in the context of wetland areas. The water features needed for investigations of flooded areas are extracted using the SWIR, green and red bands. The experiment on the Sentinel-2 subset from the Kampinos National Park in Poland shows that the combination of the water indicators $M N D W I, N D P I$ and $N D T I$ is more effective in improving the recognition of flooding, especially in wetlands, than individual spectral water indices. The idea of the proposed connection lies in the mutual complementing of spectral water indices in the recognition of flooding. While the MNDWI indicator best identifies open water, the NDPI captures vegetation in wetlands and water, and the NDTI reduces the impact of open soils that may be confused with turbid water reservoirs. As a result, features are created that are easier to distinguish between flooded areas and water bodies. However, the approach used does not work in forest areas and shows inferior effectiveness during periods of luxuriant vegetation development. The maps of the extent of flooding in non-forest areas created on the basis of the proposed method show satisfactory accuracy. In addition, the time variability of ranges and the location of flooded areas was tracked in this study. It has been seen that flooding areas are located along the rows and drainage canals that cross the privileged rainwater runoff paths. Flooding with a stable trend of variability is usually located in the undrained depressions. Future studies should use effective image sharpening algorithms that will better accommodate flooded wetlands and the spectral and spatial characteristics of the Sentinel-2 imagery.

The advantage of this approach is the separate recognition of water reservoirs and areas flooded with water with a translucent vegetal cover, which ensures the distinction between flooded areas and water reservoirs. In addition, the use of the false colour composite $R_{N D T /} G_{N D P I} B_{M N D W l}$ provides the ability to distinguish between flooded areas flooded and permanent wetlands. The results obtained in this work show that the combined $R_{N D T /} G_{N D P I} B_{M N D W l}$ index calculated on the basis of Sentinel-2 data provides satisfactory accuracy of flood mapping and can be used on non-forest areas. An additional advantage is the simple calculation method and quick mapping with limited resources, which is of particular importance when monitoring floods and classification of wetlands on a regional scale.

Acknowledgments. This paper is financially supported by the Polish Geological Institute - National Research Institute (Grant 61-8509-1701-00-0 and 62.9012.1954.00.0). The author wishes to thank the reviewers, Prof. I. Nyambe and M. Stefouli, for their very constructive suggestions and comments.

\section{REFERENCES}

Acreman, M., Holden, J., 2013. How wetlands affect floods. Wetlands, 33: 773-786.

Bourgeau-Chavez, L., Kasischke, E., Brunzell, S., Mudd, J., Smith, K., Frick, A., 2001. Analysis of space-borne SAR data for wetland mapping in Virginia Riparian Ecosystems. International Journal of Remote Sensing, 22: 3665-3687.

Brisco, B., Kaper, M., Hirose, T., Tedford, B., Liu, J., 2011. Evaluation of $\mathrm{C}$-band polarization diversity and polarimetry for wetland mapping. Canadian Journal of Remote Sensing, 37: 82-92.

Budzyńska, M., Dąbrowska-Zielińska, K., Turlej, K., Malek, L., Bartold, M., 2011. Monitoring przyrodniczy Bagien Biebrzań- skich z zastosowaniem teledetekcji (in Polish). Woda-Środowisko-Obszary Wiejskie, 3: 39-64.

Butera, M.K., 1983. Remote sensing of wetlands. IEEE Transactions on Geoscience and Remote Sensing, 3: 383-392.

Chander, G., Markham, B.L., Helder, D.L., 2009. Summary of current radiometric calibration coefficients for Landsat MSS, TM, ETM+, and EO-1 ALI sensors. Remote Sensing of Environment, 113: 893-903.

Chavez, P.S., Sides, S.C., Anderson, J.A., 1991. Comparison of 3 different methods to merge multiresolution and multispectral 
data-Landsat tm and spot panchromatic. Photogrammetric Engineering and Remote Sensing, 57: 295-303.

Chen, Q.L., Zhang, Y.Z., Ekroos, A., Hallikainen, M., 2004. The role of remote sensing technology in the EU water framework directive (WFD). Environmental Science \& Policy, 7: 267-276.

Davranche, A., Lefebvre, G., Poulin, B., 2010. Wetland monitoring using classification trees and SPOT-5 seasonal time series. Remote Sensing of Environment, 114: 552-562.

Dong, Z.Y., Wang, Z.M., Liu, D.W., Song, K.S., 2014. Mapping wetland areas using landsat-derived NDVI and LSWI: a case study of west songnen plain, Northeast China. Journal of the Indian Society of Remote Sensing, 42: 569-576.

Drusch, M., Del Bello, U., Carlier, S., Colin, O., Fernandez, V., Gascon, F., Hoersch, B., Isola, C., Laberinti, P., Martimort, P., Meygret, A., Spoto, F., Sy, O., Marchese, F., Bargellini, P., 2012. Sentinel-2: ESA's optical high-resolution mission for GMES operational services. Remote Sensing of Environment, 120: $25-36$.

Du, Y., Xue, H.P., Wu, S.J., Ling, F., Xiao, F., Wei, X.H., 2011. Lake area changes in the middle Yangtze region of China over the 20th century. Journal of Environmental Management, 92 1248-1255.

Du, Z.Q., Li, W.B., Zhou, D.B., Tian, L.Q., Ling, F., Wang, H.L., Gui, Y.M., Sun, B.Y., 2014. Analysis of Landsat-8 OLI imagery for land surface water mapping. Remote Sensing, 5: 672-681.

Dvorett, D., Davis, C., Papes, M., 2016. Mapping and hydrologic attribution of temporary wetlands using recurrent Landsat imagery. Wetlands, 36: 431-443.

Feng, L., Hu, C.M., Chen, X.L., Cai, X.B., Tian, L.Q., Gan, W.X., 2012. Assessment of inundation changes of Poyang Lake using MODIS observations between 2000 and 2010. Remote Sensing of Environment, 121: 80-92.

Foody, G.M., 2002. Status of land cover classification accuracy assessment. Remote Sensing of Environment, 80: 185-201.

Gao, B.C., 1996. NDWI - A normalized difference water index for remote sensing of vegetation liquid water from space. Remote Sensing of Environment, 58: 257-266.

Guyot, G., 1989. Signatures spectrales des surfaces naturelles. Télédétection satellitaire, 5, Col. SAT, Ed. Paradigme.

Huang, C., Chen, Y., Wu, J.P., 2014a. DEM-based modification of pixel-swapping algorithm for enhancing floodplain inundation mapping. International Journal of Remote Sensing, 35 365-381.

Huang, C.Q., Peng, Y., Lang, M.G., Yeo, I.Y., McCarty, G., 2014b. Wetland inundation mapping and change monitoring using Landsat and airborne LiDAR data. Remote Sensing of Environment, 141: 231-242.

Huete, A., Liu, H., Batchily, K.V., Van Leeuwen, W., 1997. A comparison of vegetation indices over a global set of TM images for EOS-MODIS. Remote Sensing of Environment, 59: 440-451.

Ilnicki, P., 2002. Torfowiska i torf (in Polish). AR Poznań.

Islam, M., Sado, K., 2006. Analyses of ASTER and spectroradiometer data with in situ measurements for turbidity and transparency study of lake Abashri. International Journal of Geo-Information, 2: 31-45.

Jensen, J.R., 1996. Introductory Digital Image Processing, a Remote Sensing Perspective. Second edition. Prentice Hall, Upper Saddle River, New Jersey.

Jones, K., Lanthier, Y., van der Voet, P., van Valkengoed, E., TayIor, D., Fernández-Prieto, D., 2009. Monitoring and assessment of wetlands using Earth Observation: the GlobWetland project. Journal of Environmental Management, 90: 2154-2169.

Kasischke, E., Smith, K., Bourgeau-Chavez, L., Romanowicz, E., Brunzell, S., Richardson, C., 2003. Effects of seasonal hydrologic patterns in south florida wetlands on radar backscatter measured from ERS-2 SAR imagery. Remote Sensing of Environment, 88: 423-441.
Kayastha, N., Thomas, V., Galbraith, J., Banskota, A., 2012. Monitoring wetland change using inter-annual Landsat time-series data. Wetlands, 32: 1149-1162.

Kayranli, B., Scholz, M., Mustafa, A., Hedmark, A., 2009. Carbon storage and fluxes within freshwater wetlands: a critical review. Wetlands, 30: 111-124.

Ko, B.C., Kim, H.H., Nam, J.Y., 2015. Classification of potential water bodies using landsat $8 \mathrm{OLI}$ and a combination of two boosted random forest classifiers. Sensors, 15: 13763-13777.

Kopeć, D., Michalska-Hejduk, D., Krogulec, E., 2013. The relationship between vegetation and groundwater levels as an indicator of spontaneous wetland restoration. Ecological Engineering, 57: 242-251.

Krogulec, E., 2004. Ocena podatności wód podziemnych na zanieczyszczenia w dolinie rzecznej na podstawie przesłanek hydrodynamicznych (in Polish). Wyd. Uniwersytetu Warszawskiego, Warszawa.

Krogulec, E., 2011. Charakterystyka uwarunkowań hydroekologicznych (in Polish). In: Ochrona i renaturyzacja mokradeł Kampinoskiego Parku Narodowego (eds. T. Okruszko, W. Mioduszewski and L. Kucharski): 73-92. Wydawnictwo SGGW, Warszawa.

Lacaux, J.P., Tourre, Y.M., Vignolles, C., Ndione, J.A., Lafaye, M., 2007. Classification of ponds from highspatial resolution remote sensing: Application to Rift Valley Fever epidemics in Senegal. Remote Sensing of Environment, 106: 66-74.

Lewiński, S., 2007. Obiektowa klasyfikacja zdjęć satelitarnych jako metoda pozyskiwania informacji o pokryciu i użytkowaniu ziemi (in Polish). Instytut Geodezji i Kartografii, Seria monograficzna, 12. Warszawa.

Li, J.H., Chen, W.J., 2005. A rule-based method for mapping Canada's wetlands using optical, radar and DEM data. International Journal of Remote Sensing, 26: 5051-5069.

Li, W.B., Du, Z.Q., Ling, F., Zhou, D.B., Wang, H.L., Gui, Y.M., Sun, B.Y., Zhang, X.M., 2013. A comparison of land surface water mapping using the normalized difference water index from TM, ETM plus and ALI. Remote Sensing, 5: 5530-5549.

Li, W., Qin, Y., Sun, Y., Huang, H., Ling, F., Tian, L., Ding, Y., 2016. Estimating the relationship between dam water level and surface water area for the Danjiangkou Reservoir using Landsat remote sensing images. Remote Sensing Letters, 7: 121-130.

Loveline, E., 2015. Impacts of wetland degradation in Niger delta Nigeria and its significance in flood control. International Journal of Remote Sensing, 4: 177-184.

Łachacz, A., 2004. Mokradła w krajobrazie - wybrane pojęcia (in Polish). Woda-Środowisko-Obszary-Wiejskie 4, 2a (11): 295-301.

Martinez, J., Le Toan, T., 2007. Mapping of flood dynamics and spatial distribution of vegetation in the Amazon Floodplain using multitemporal SAR data. Remote Sensing of Environment, 108: 209-223.

McFeeters, S.K., 1996. The use of the normalized difference water index (NDWI) in the delineation of open water features. International Journal of Remote Sensing, 17: 1425-1432.

Melack, J.M., Hess, L.L., 2010. Remote sensing of the distribution and extent of wetlands in the Amazon basin. Ecological Studies, 210: 43-59.

Michalska-Hejduk, D., 2001. Stan obecny i kierunki zmian roślinności nieleśnej Kampinoskiego Parku Narodowego. Monographia botanica, 89: 1-134.

Michalska-Hejduk, D., 2004. Najcenniejsze przyrodniczo obszary łąk i turzycowisk zachodniej części Kampinoskiego Parku Narodowego oraz propozycje ich ochrony(in Polish). Parki Narodowe Rezerwaty Przyrody, 23: 203-218.

Michalska-Hejduk, D., Kopeć, D., Kucharski, L., Kębłowska, A., Otręba, A., Kloss, M., Dembek, A., 2011. Roślinność terenów mokradłowych - stan zachowania i tendencje dynamiczne (in Polish). In: Ochrona i renaturyzacja mokradeł Kampinoskiego Parku Narodowego (eds. T. Okruszko, W. Mioduszewski and L. Kucharski): 119-141. Wydawnictwo SGGW, Warszawa. 
Mitsch, W.J., 2009. Wetland ecosystems: John Wiley \& Sons.

Mitsch, W.J., Gosselink, J.G., 2015. Wetlands. 5th ed: 155-204. Wiley, Hoboken, NJ, USA.

Monserud, R.A., Leemans, R., 1992. Comparing global vegetation maps with the Kappa statistic. Ecological Modelling, 62 275-293.

Morandeira, N.S., Grings, F., Facchinetti, C., Kandus, P., 2016 Mapping plant functional types in floodplain wetlands: an analysis of C-Band polarimetric SAR data from RADARSAT-2. Remote Sensing, 8: 174.

Moser, L., Schmitt, A., Wendleder, A., Roth, A., 2016. Monitoring of the lac Bam wetland extent using dual-polarized X-band SAR data. Remote Sensing, 8: 302.

Mwita, E., Menz, G., Misana, S., Becker, M., Kisanga, D., Boehme, B., 2013. Mapping small wetlands of Kenya and Tanzania using remote sensing techniques. International Journal of Applied Earth Observation and Geoinformation, 21: 173-183.

Nandi, I., Srivastava, P.K., Shah, K., 2017. Floodplain mapping through support vector machine and optical/infrared images from Landsat 8 OLI/TIRS sensors: case study from Varanasi. Water Resources Management, 31: 1157-1171.

Napiórkowska, M., 2014. Monitoring wetlands ecosystems using ALOS PALSAR (L-Band, HV) supplemented by optical data: a case study of Biebrza Wetlands in Northeast Poland. Remote Sensing, 6: 1605-1633.

Okruszko, T., Mioduszewski, W., Kucharski, L., 2011. Ochrona renaturyzacja mokradeł Kampinoskiego Parku Narodowego (in Polish). Wydawnictwo SGGW, Warszawa.

Olszewski, A., Wierzbicki, A., Degórska, A., Ferchmin, M., Gudowicz, J., Lenartowicz, M., Otręba, N., 2018. Raport stacji bazowej zintegrowanego monitoringu środowiska przyrodniczego „Pożary” za rok 2017 (in Polish). Maszynopis KPN, Izabelin.

Ramsey, E.W., Laine, S.C., 1997. Comparison of Landsat thematic mapper and high resolution photography to identify change in complex coastal wetlands. Journal of Coastal Research, 13: 281-292.

Seiler, R., Schmidt, J., Diallo, O., Csaplovics, E., 2009. Flood monitoring in a semi-arid environment using spatially high resolution radar and optical data. Journal of Environmental Management, 90: 2121-2129.
Selva, M., Aiazzi, B., Butera, F., Chiarantini, L., Baronti, S., 2015. Hyper-sharpening: a first approach on SIM-GA data. International Journal of Applied Earth Observation and Geoinformation and Remote Sensing, 8: 3008-3024.

Singh, K.V., Setia, R., Sahoo, S., Prasad, A., Pateriya, B., 2015 Evaluation of NDWI and MNDWI for assessment of waterlogging by integrating digital elevation model and groundwater level. Geocarto International, 30: 650-661.

Solovey, T., 2013. Zastosowanie metod teledetekcyjnych do identyfikacji obszarów podmokłych na Nizinach Środkowopolskich (in Polish). Biulletyn Państwowego Instytutu Geologicznego, 454: 133-139.

Solovey, T., 2017. Identification of the Rozwarowo Marshes using radar remote sensing. Geographia Polonica, 90: 431-440.

Sun, F.D., Sun, W.X., Chen, J., Gong, P., 2012. Comparison and improvement of methods for identifying waterbodies in remotely sensed imagery. International Journal of Remote Sensing, 33: 6854-6875.

Tobolski, K., 2003. Torfowiska na przykładzie Ziemi Świeckiej (in Polish). Wyd. Towarzystwo Przyjaciół Dolnej Wisły, Świecie.

Tucker, C.J., Sellers, P.J., 1986. Satellite remote sensing of primary productivity. International Journal of Remote Sensing, 7: 1395-1416.

White, L., Brisco, B., Dabboor, M., Schmitt, A., Pratt, A., 2015. A collection of SAR methodologies for monitoring wetlands. Remote Sensing, 7: 7615-7645.

Whyte, A., Ferentinos, K.P., Petropoulos, G.P., 2018. A new synergistic approach for monitoring wetlands using Sentinels-1 and 2 data with object-based machine learning algorithms. Environmental Modelling \& Software, 104: 40-54.

Wu, Q., 2018. GIS and remote sensing applications in wetland mapping and monitoring. Comprehensive Geographic Information Systems, 2: 140-157.

Xu, H.Q., 2006. Modification of normalised difference water index (NDWI) to enhance open water features in remotely sensed imagery. International Journal of Remote Sensing, 27: 3025-3033.

Zomer, R.J., Trabucco, A., Ustin, S., 2009. Building spectral libraries for wetlands land cover classification and hyperspectral remote sensing. Journal of Environmental Management, 90: 2170-2177. 